\title{
Oxygenated polycyclic aromatic hydrocarbons from ambient particulate matter induce electrophysiological instability in cardiomyocytes
}

Sujin Ju' ${ }^{1}$, Leejin Lim ${ }^{1,2}$, Han-Yi Jiao ${ }^{3}$, Seok Choi ${ }^{3}$, Jae Yeoul Jun ${ }^{3}$, Young-Jae Ki ${ }^{4}$, Dong-Hyun Choi ${ }^{4}$, Ji yi Lee ${ }^{5^{*}}$ and Heesang Song ${ }^{1,6^{*}}$ (1)

\begin{abstract}
Background: Epidemiologic studies have suggested that elevated concentrations of particulate matter (PM) are strongly associated with an increased risk of developing cardiovascular diseases, including arrhythmia. However, the cellular and molecular mechanisms by which PM exposure causes arrhythmia and the component that is mainly responsible for this adverse effect remains to be established. In this study, the arrhythmogenicity of mobilized organic matter from two different types of PM collected during summer (SPM) and winter (WPM) seasons in the Seoul metropolitan area was evaluated. In addition, differential effects between polycyclic aromatic hydrocarbons (PAHs) and oxygenated PAHs (oxy-PAHs) on the induction of electrophysiological instability were examined.

Results: We extracted the bioavailable organic contents of ambient PM, measuring $10 \mu \mathrm{m}$ or less in diameter, collected from the Seoul metropolitan area using a high-volume air sampler. Significant alterations in all factors tested for association with electrophysiological instability, such as intracellular $\mathrm{Ca}^{2+}$ levels, reactive oxygen species (ROS) generation, and mRNA levels of the $\mathrm{Ca}^{2+}$-regulating proteins, sarcoplasmic reticulum $\mathrm{Ca}^{2+}$ ATPase (SERCA2a), $\mathrm{Ca}^{2+} /$ calmodulin-dependent protein kinase II (CaMK II), and ryanodine receptor 2 (RyR2) were observed in cardiomyocytes treated with PM. Moreover, the alterations were higher in WPM-treated cardiomyocytes than in SPM-treated cardiomyocytes. Three-fold more oxy-PAH concentrations were observed in WPM than SPM. As expected, electrophysiological instability was induced higher in oxy-PAHs (9,10-anthraquinone, AQ or 7,12-benz(a) anthraquinone, BAQ)-treated cardiomyocytes than in PAHs (anthracene, ANT or benz(a) anthracene, BaA)-treated cardiomyocytes; oxy-PAHs infusion of cells mediated by aryl hydrocarbon receptor (AhR) was faster than PAHs infusion. In addition, ROS formation and expression of calcium-related genes were markedly more altered in cells treated with oxy-PAHs compared to those treated with PAHs.

(Continued on next page)
\end{abstract}

\footnotetext{
* Correspondence: yijiyi@ehwa.ac.kr; hsong@chosun.ac.kr

${ }^{5}$ Department of Environmental Science and Engineerings, Ewha Womans University, Seoul 03760, South Korea

'Department of Biomaterials, Chosun University Graduate School, Gwangju 61452, South Korea

Full list of author information is available at the end of the article
}

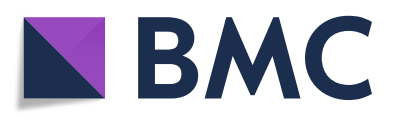

(- The Author(s). 2020 Open Access This article is licensed under a Creative Commons Attribution 4.0 International License, which permits use, sharing, adaptation, distribution and reproduction in any medium or format, as long as you give appropriate credit to the original author(s) and the source, provide a link to the Creative Commons licence, and indicate if changes were made. The images or other third party material in this article are included in the article's Creative Commons licence, unless indicated otherwise in a credit line to the material. If material is not included in the article's Creative Commons licence and your intended use is not permitted by statutory regulation or exceeds the permitted use, you will need to obtain permission directly from the copyright holder. To view a copy of this licence, visit http://creativecommons.org/licenses/by/4.0/. The Creative Commons Public Domain Dedication waiver (http://creativecommons.org/publicdomain/zero/1.0/) applies to the data made available in this article, unless otherwise stated in a credit line to the data. 
(Continued from previous page)

Conclusions: The concentrations of oxy-PAHs in PM were found to be higher in winter than in summer, which might lead to greater electrophysiological instability through the ROS generation and disruption of calcium regulation.

Keywords: Ambient particulate matter, Oxygenated polycyclic aromatic hydrocarbons, Electrophysiological instability, Cardiomyocytes, Reactive oxygen species

\section{Background}

Exposure to ambient particulate matter (PM) is associated with increased cardiovascular morbidity and mortality. After revealing the association between PM exposure and the causative risks involved in all mortality cases in the US [1], various epidemiological and experimental studies have reported that elevated PM concentrations were closely associated with increase in cardiovascular diseases (CVD), including myocardial infarction, stroke, arrhythmia, and venous thromboembolism [2-4]. In addition, epidemiological studies have shown a positive correlation between elevated levels of PM and the incidence of life-threatening ventricular arrhythmias [5, 6]. However, most previous studies have only focused on revealing epidermiological correlations between air pollution and the prevalence of CVD $[7,8]$, especially arrhythmia, although few other studies emphasized on the underlying mechanisms in cardiomyocytes [9]. Indeed, experimental studies have suggested that PM exposure increases cardiac oxidative stress and electrophysiological changes in rats $[10,11]$. In addition, Kim et al. demonstrated that arrhythmic parameters, such as action potential duration (APD), early afterdepolarization (EAD), and ventricular tachycardia (VT), were significantly increased in diesel exhausted particle (DEP)-infused rat hearts due to oxidative stress and calcium kinase II activation [9].

Ambient PM, composed natural and anthropogenic particles, is a complex mixture of organic and inorganic compounds [12]. In particular, there is growing evidence that polycyclic aromatic hydrocarbons (PAHs) and their oxygenated derivatives (oxy-PAHs), which are major organic components of ambient PM, play an important role in the correlation between air pollution and increased cardiovascular morbidity and mortality rates [13-15]. PAHs and oxy-PAHs are found in cigarette smoke and are generated by different combustion processes in urban environments; the sources of PAHs and oxy-PAHs include motor vehicles, residential heating, fossil fuel combustion in energy and industrial processes, and municipal and medical incinerators [16, 17]. In addition, oxy-PAHs also originate from reactions between PAHs and hydroxyl radicals, nitrate radicals, other organic and inorganic radicals, and ozone [18], or from photo-oxidation of PAHs by singlet molecular oxygen
[19]. The carcinogenic potential of various PAHs, which may act as major contributors to the mutagenic activity of ambient PM, have been reported [20, 21]. Moreover, it has been demonstrated that oxy-PAHs have the highest human-cell mutagenic potential of all respirable airborne particles in the northeastern United States [21]. In addition, because of their ability to oxidize nucleic acids, proteins, and lipids, oxy-PAHs might also induce severe redox stress in cells and tissues [3-5]. Therefore, we hypothesize that oxy-PAHs induce more severe arrhythmia than PAHs via oxidative stress. To test this hypothesis and identify the underlying mechanisms of oxy-PAHs induced arrhythmia, we compared seasonal concentrations of PAHs and oxy-PAHs and the amount of oxidative stress induced by these compounds in cardiomyocytes. Further, we determined the levels of ROS and electrophysiological alterations caused by selected PAHs and oxy-PAHs.

\section{Results \\ Ambient particles promotes electrophysiological instability}

To investigate electrophysiological alterations caused by ambient PM, we analyzed the action potential parameters using a patch clamp system. As shown in Fig. 1a, ambient PM rapidly increased the action potential (AP) frequency, depolarized the resting membrane potential (RMP), and reduced the action potential amplitude (APA). Importantly, ambient PM increased the action potential duration (APD) for both 50 and 90\% repolarization $\left(\mathrm{APD}_{50}\right.$ and $\left.\mathrm{APD}_{90}\right)$. We observed that $\mathrm{APD}$ increased immediately after switching to PM-containing solution; it increased with time and reached a steady state within $5 \mathrm{~min}$. The induced electrophysiological instability was remarkably higher in WPM-treated cardiomyocytes than in SPM-treated cardiomyocytes. We then investigated the ROS generation and subsequent intracellular $\mathrm{Ca}^{2+}$ disturbance by ambient PM using a fluorescence assay. As seen in Fig. 1c, ROS generation was significantly increased in a dose-dependent manner in cardiomyocytes treated with ambient PM collected in both summer and winter. The increase in ROS generation was greater in WPM-treated cardiomyocytes than in SPM-treated cardiomyocytes. Intracellular $\mathrm{Ca}^{2+}$ contents showed a similar trend as ROS generation (Fig. 1c). 


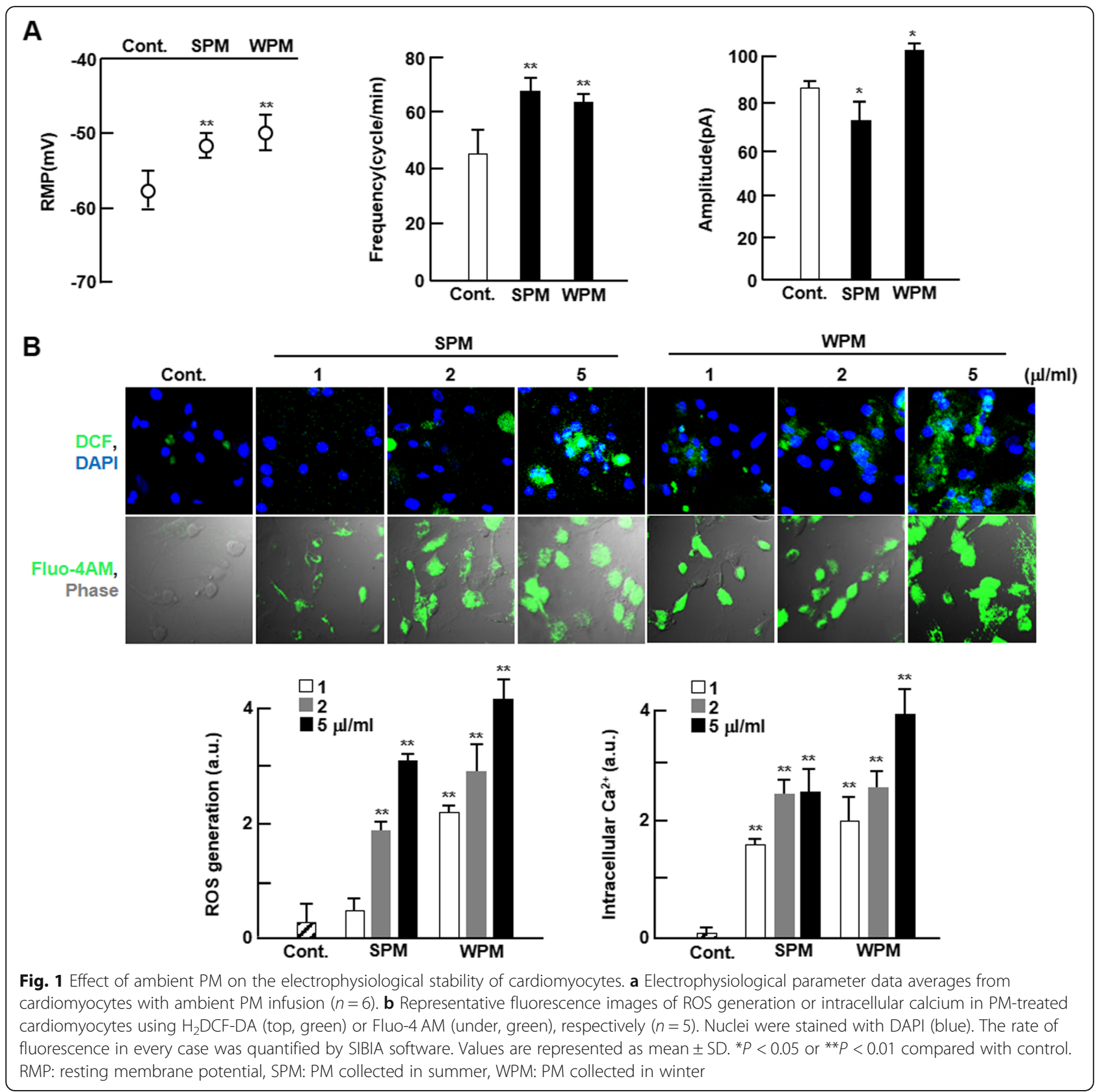

Ambient particles regulate expression of $\mathrm{Ca}^{2+}$-related genes and the dependent signaling pathways

The effects of ambient PM on $\mathrm{Ca}^{2+}$ related genes in cardiomyocytes were investigated. The contraction of cardiomyocytes is triggered by the influx of $\mathrm{Ca}^{2+}$ into the cytosol through voltage-gated L-type $\mathrm{Ca}^{2+}$ channels, and this influx initiates the release of $\mathrm{Ca}^{2+}$ from the sarcoplasmic reticulum (SR) via ryanodine receptor 2 (RyR2). For relaxation, there is a rapid $\mathrm{Ca}^{2+}$ reuptake into the SR through SR $\mathrm{Ca}^{2+}$-ATPase (SERCA2a) and extrusion via $\mathrm{Na}^{+} / \mathrm{Ca}^{2+}$-exchanger (NCX). Calmodulin kinase II (CaMKII) phosphorylates RyR2 to enhance $\mathrm{SR} \mathrm{Ca}^{2+}$ release [22]. mRNA expression levels of CaMKII and RyR2 increased in a dose-dependent manner in cardiomyocytes treated with both SPM and WPM. SERCA2a was significantly decreased in cardiomyocytes treated with WPM but not with SPM. Interestingly, we evaluated the altered levels of all NCX isoforms, NCX1, NCX2, and NCX3, and identified that only the levels of NCX2 mRNA were altered and this chage was only observed at the highest concentration of SPM-treated cardiomyocytes and at all concentrations of WPM-treated cardiomyocytes (Fig. 2a). The data for NCX1 and 3 are not shown. We observed that the phosphorylated levels 


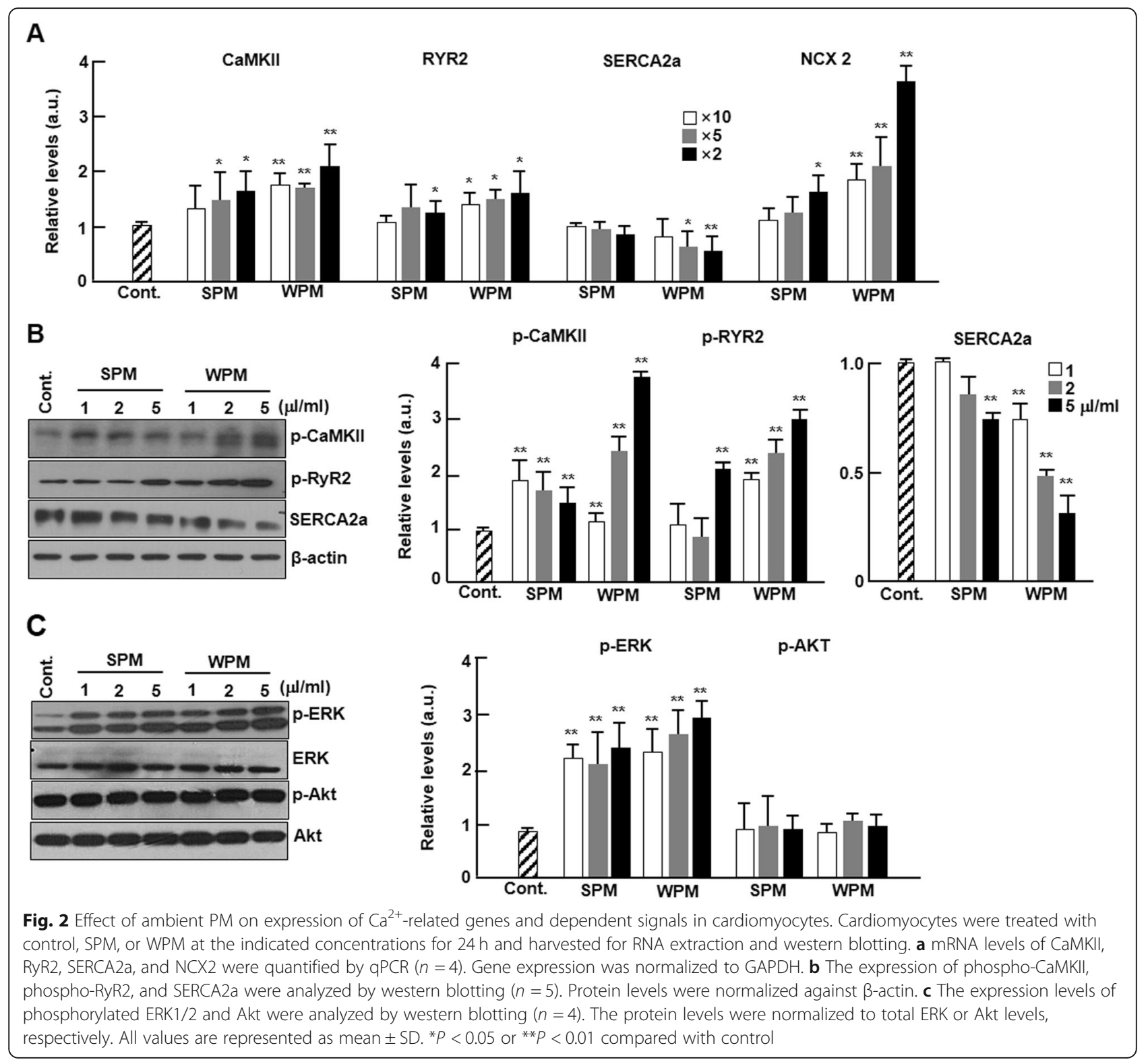

of CaMKII and RyR2 and the protein expression levels of SERCA2a were significantly altered in a similar manner as the mRNA expression levels, demonstrating that the ROS generated by ambient PM not only affected the expression but also the activity of calcium-regulating genes in cardiomyocytes (Fig. 2b). Furthermore, the levels of phosphorylated ERK dramatically increased in ambient particletreated cardiomyocytes, but the levels of phosphorylated Akt did not appear to be altered (Fig. 2c).

\section{Scavenging of ROS by NAC attenuates the} electrophysiological instability due to ambient particles To confirm that the induction of electrophysiological instability in cardiomyocytes by ambient PM was specifically due to ROS, we investigated the effects of ROS scavenger,
$\mathrm{N}$-acetyl cysteine (NAC), on electrophysiological alterations caused by ambient PM using a patch clamp system. As shown in Fig. 3a, treatment with NAC resulted in a significant improvement in AP frequency, depolarized RMP, $A P A$, and $A D_{50}$ and $A P D_{90}$ values. We observed that ROS generation and intracellular $\mathrm{Ca}^{2+}$ contents were successfully attenuated in PM-treated cardiomyocytes by NAC treatment (Fig. 3b and c). In addition, alterations in mRNA or protein expression levels of CaMKII, RyR2, and SERCA2a by PM were rescued by NAC treatment (Fig. 3d and e).

PAHs and oxy-PAHs result in differential ROS generation and $\mathrm{Ca}^{2+}$ perturbations

Ambient particles collected in the Seoul metropolitan area contain organic matter, such as PAHs and oxy- 

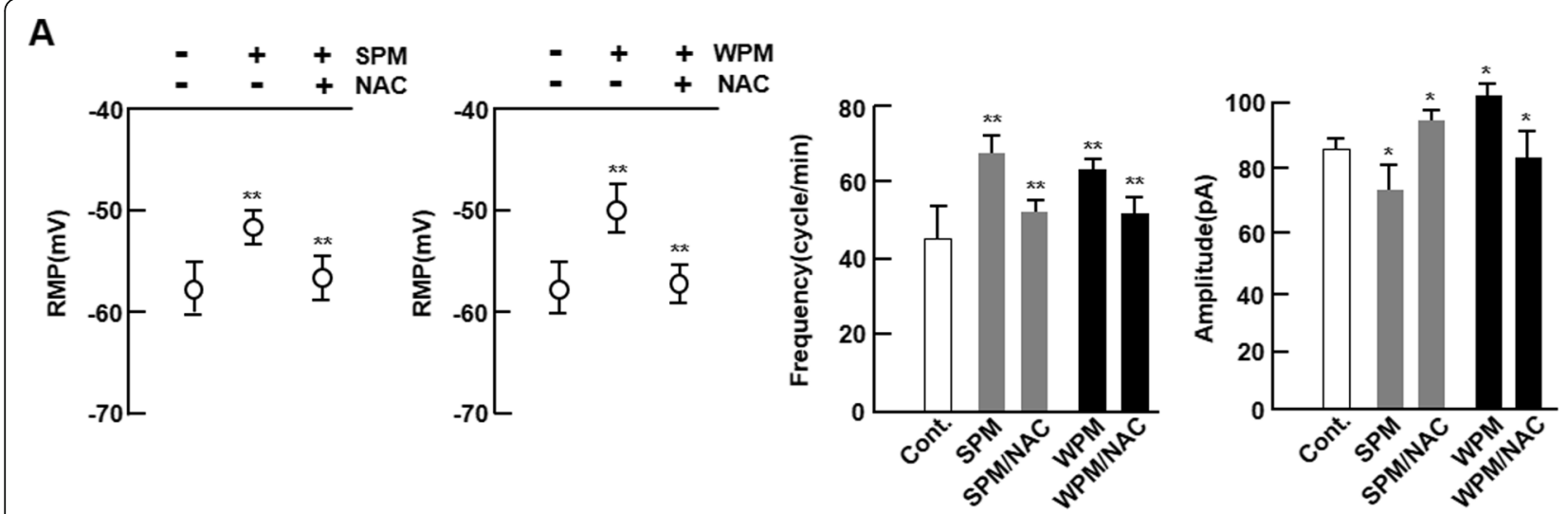

B

C

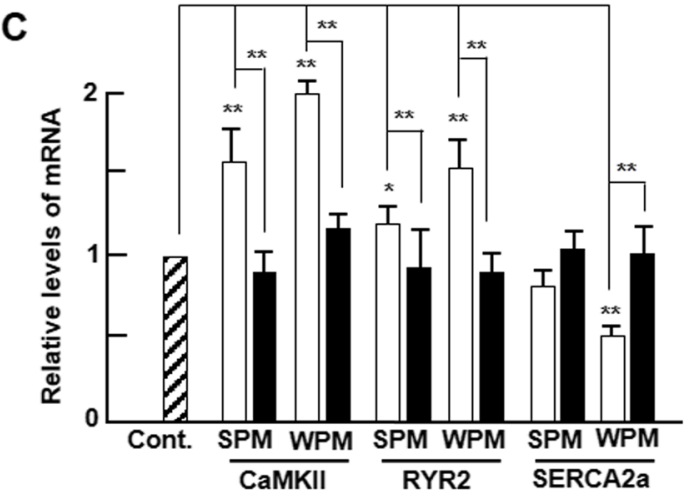

D
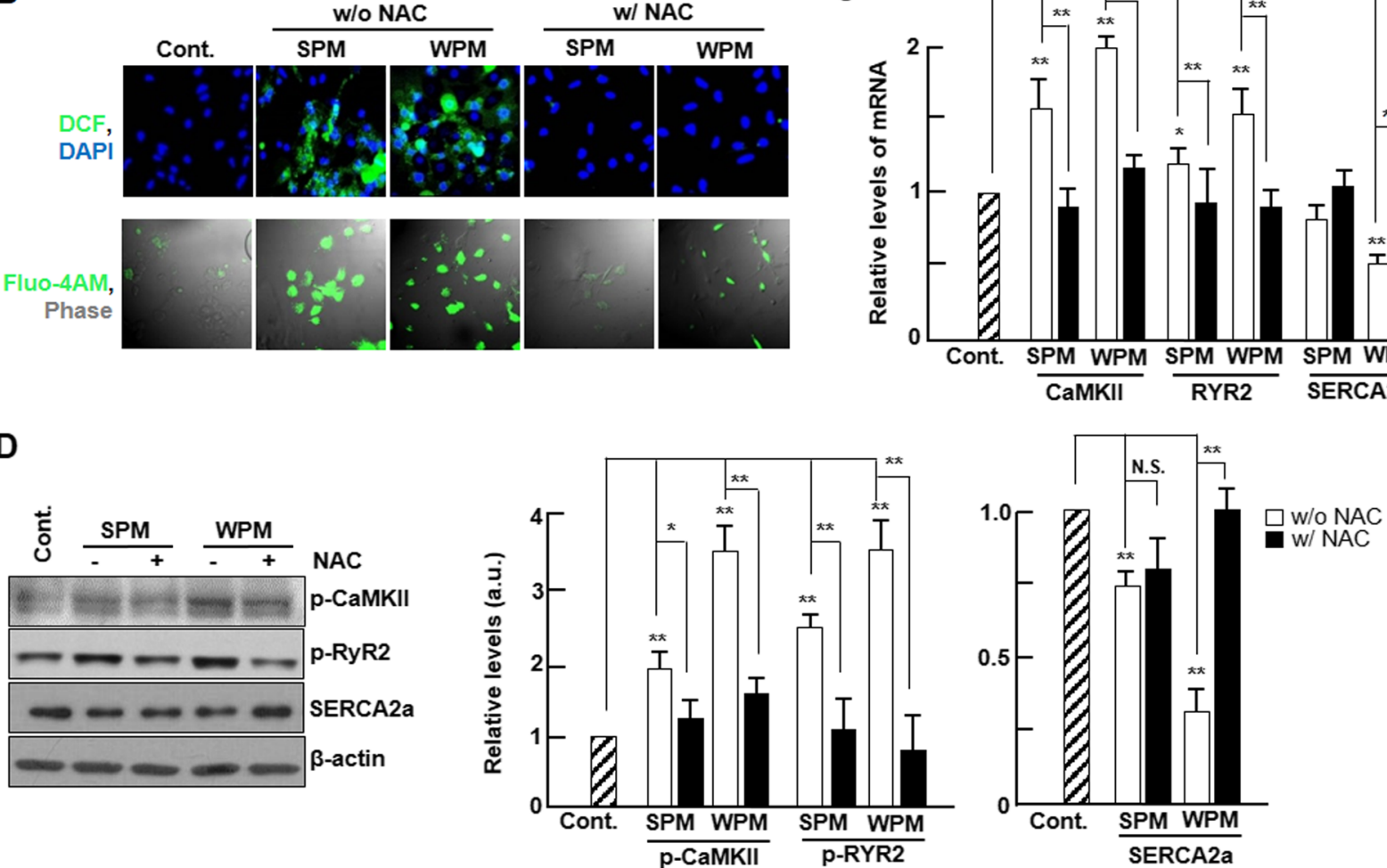

Fig. 3 Effect of an ROS scavenger on the electrophysiological stability of cardiomyocytes. a Electrophysiological parameter data averages from cardiomyocytes with ambient PM infusion with or without NAC $(n=4)$. b Representative fluorescence images of ROS generation or intracellular calcium in PM-treated cardiomyocytes with or without NAC using $\mathrm{H}_{2}$ DCF-DA (top, green) or Fluo-4 AM (under, green), respectively $(n=4)$. Nuclei were stained with DAPI (blue). The rate of fluorescence for every sample was quantified by SIBIA software. c The mRNA levels of CaMKII, RyR2, and SERCA2a in the absence or presence of NAC were quantified by qPCR $(n=4)$. Gene expression levels were normalized to GAPDH. $\mathbf{d}$ The expression levels of phospho-CaMKII, phospho-RyR2, and SERCA2a in the absence or presence of NAC were analyzed by western blotting $(n=5)$. Protein levels were normalized to $\beta$-actin. Values are represented as mean \pm SD. ${ }^{*} P<0.05$ or ${ }^{* *} P<0.01$ compared with non-treated controls

PAHs, that might act as key mediators of ROS generation. As shown in Table 1, both PAHs and oxy-PAHs were contained with higher concentrations in WPM than SPM. In addition, we presented a standardized ratio of individual PAHs and oxy-PAHs mobilized from PM to organic carbon (OC) concentrations (Table 1). As shown in Table 1 , ratio of PAHs and oxy-PAHs in WPM were 3-5 fold greater than those in SPM even though OC concentration in SPM and WPM are similar. We, therefore, hypothesized that PAHs and their oxygenated derivatives are the main components of ambient PM that induce electrophysiological instability in cardiomyocytes. We investigated the effects of the two kinds of PAHs (Table 2), anthracene (ANT) and benz(a) anthracene $(\mathrm{BaA})$, and their oxygenated derivatives, 9,10anthraquinone (AQ) and 7,12-benz(a) anthraquinone 
Table 1 Concentrations of PAHs and oxy-PAHs with ratio of composition in OC of ambient PM10

\begin{tabular}{|c|c|c|c|c|c|c|}
\hline \multirow[t]{2}{*}{ Organic compounds } & \multicolumn{3}{|l|}{ SPM } & \multicolumn{3}{|l|}{ WPM } \\
\hline & $\mathrm{ng} / \mathrm{m}^{3, a)}$ & $\mathrm{ng} / \mathrm{mL}^{\mathrm{b})}$ & $(\mathrm{ng} / \mu \mathrm{g})^{*} 100^{c)}$ & $\overline{\mathrm{ng} / \mathrm{m}^{3}}$ & $\mathrm{ng} / \mathrm{mL}$ & $(\mathrm{ng} / \mu \mathrm{g})^{*} 100$ \\
\hline \multicolumn{7}{|l|}{ PAHs } \\
\hline Phenanthrene & 0.09 & 0.36 & 1.7 & 2.44 & 9.84 & 31.2 \\
\hline Anthracene & - & - & 0.0 & 0.23 & 0.93 & 2.9 \\
\hline Fluoranthene & 0.23 & 0.93 & 4.4 & 2.78 & 11.21 & 35.4 \\
\hline Pyrene & 0.23 & 0.93 & 4.4 & 2.03 & 8.18 & 26.0 \\
\hline Retene & - & - & 0.0 & 1.31 & 5.28 & 16.7 \\
\hline Benz [a]anthracene & 0.24 & 0.97 & 4.7 & 0.98 & 3.95 & 12.5 \\
\hline Chrysene & 0.17 & 0.69 & 3.2 & 0.90 & 3.63 & 11.5 \\
\hline Benzo [b]fluoranthene & 0.41 & 1.65 & 7.8 & 1.41 & 5.69 & 18.0 \\
\hline Benzo [k]fluoranthene & 0.25 & 1.01 & 4.9 & 1.16 & 4.68 & 14.8 \\
\hline Benzo [e]pyrene & 0.20 & 0.81 & 3.9 & 0.93 & 3.75 & 11.9 \\
\hline Benzo [a]pyrene & 0.21 & 0.85 & 4.1 & 1.00 & 4.03 & 12.7 \\
\hline Indeno[1,2,3-cd]fluoranthene & 0.04 & 0.16 & 0.8 & 0.39 & 1.57 & 5.0 \\
\hline Dibenz $[a, h]$ anthracene & 0.05 & 0.20 & 0.9 & 0.47 & 1.90 & 6.0 \\
\hline Indeno[1,2,3-cd]pyrene & 0.17 & 0.69 & 3.3 & 1.43 & 5.77 & 18.3 \\
\hline Benzoperylene & 0.16 & 0.65 & 3.0 & 1.07 & 4.31 & 13.7 \\
\hline Coronene & 0.07 & 0.28 & 1.4 & 0.80 & 3.23 & 10.3 \\
\hline Total & 2.53 & 10.21 & 48.5 & 19.32 & 77.89 & 246.9 \\
\hline \multicolumn{7}{|l|}{ Oxy-PAHs } \\
\hline 1,4-Naphthalenedione & 0.47 & 1.90 & 8.0 & 1.12 & 4.52 & 18.1 \\
\hline 9,10-Anthracenedione & 0.37 & 1.49 & 7.7 & 1.37 & 5.52 & 17.3 \\
\hline 9-Fluorenone & 0.73 & 2.94 & 18.1 & 0.67 & 2.70 & 8.7 \\
\hline Perinaphthenone & - & - & - & 2.38 & 9.60 & 28.0 \\
\hline Xanthone & - & - & & 0.47 & 1.90 & 5.5 \\
\hline 5,12-Naphthacenedione & - & - & - & - & - & - \\
\hline Benz [a]anthracene-1,12-dione & - & - & - & 0.79 & 3.19 & 10.6 \\
\hline Total & 1.57 & 6.33 & 33.8 & 6.80 & 27.42 & 88.2 \\
\hline \multicolumn{7}{|l|}{ Carbon species } \\
\hline Organic Carbon (OC) & 5.20 & 20.97 & & 7.83 & 31.57 & \\
\hline Elementary Carbon (EC) & 1.82 & 7.34 & & 1.96 & 790 & \\
\hline Water Soluble OC (WSOC) & 2.20 & 8.87 & & 3.56 & 14.35 & \\
\hline
\end{tabular}

SPM and WPM are particulate matters collected in the Seoul metropolitan area during summer and winter seasons, respectively

a) Ambient concentrations of individual compounds

b) Injected concentrations to cells

c) Ratio of individual compounds in $\mathrm{OC}$

(BAQ), on ROS generation and $\mathrm{Ca}^{2+}$ perturbation in cardiomyocytes. Concentrations of $0.5,1$, and $10 \mu \mathrm{M}$ PAHs or oxy-PAHs were used in this test and were shown to have no significant effects on cardiomyocyte viability (data not shown). As shown in Fig. 4a and b, ROS generation and intracellular $\mathrm{Ca}^{2+}$ contents significantly increased in cardiomyocytes treated with each $\mathrm{PAH}$ and oxy-PAH in a dose-dependent manner. As expected, we observed that the alterations were notably greater in cardiomyocytes treated with oxy-PAHs than in those treated with PAHs.

mRNA expression of SERCA2a significantly decreased only in cardiomyocytes treated with $10 \mu \mathrm{M}$ ANT and 1 and $10 \mu \mathrm{M}$ of $\mathrm{BaA}$, but the expression levels significantly decreased in cardiomyocytes treated with all concentrations of oxy-PAHs, AQ, and BAQ (Fig. 4c). The protein expression levels of SERCA2a also significantly decreased in cardiomyocytes treated with all concentrations of BAQ. 
Table 2 Characteristics of PAHs and oxy-PAHs used in this study

\begin{tabular}{lll}
\hline Compound & Abbreviated name \\
PAHs & AnTthracene \\
Benz-PAHs \\
9,10-Anthraquinone
\end{tabular}

However, there were no alterations in ANT-treated cardiomyocytes and a significant decrease was observed only in $10 \mu \mathrm{M} \mathrm{AQ}$ and BaA-treated cells (Fig. 4d). Interestingly, SERCA2a activities were significantly decreased by at least 2-fold for all concentrations of oxy-PAHs, AQ, and BAQ, but no changes were observed for PAHs, ANT, and BaA (Fig. 5a). It has been known that intracellular ROS might catalyze protein carbonylation [23] and malondialdehyde (MDA) formation [24]. Protein carbonylation was significantly increased in the $\mathrm{H}_{2} \mathrm{O}_{2}$-treated positive controls (Fig. 5b). We did not observe protein carbonylation in $\mathrm{BaA}$-treated cardiomyocytes, whereas there was a significant increase in oxy-PAHs-, AQ-, and BAQ-treated cells. There was also a significant increase in protein carbonylation level in ANT-treated cardiomyocytes, but the increase was lower than in cells treated with oxy-PAHs (Fig. 5b). MDA formation was also increased in all samples, and the increase was greater in oxy-PAHs- than in PAHs-treated cardiomyocytes (Fig. 5c). Furthermore, phosphorylated ERK levels were dramatically increased in cardiomyocytes treated with each of the four PAHs, but this increase was greater in cardiomyocytes treated with oxy-PAHs than in those treated with PAHs (Fig. 5d). Phosphorylated Akt increased only when the cells were treated with $10 \mu \mathrm{M}$ of ANT and all concentrations of AQ (Fig. 5d).

\section{The aryl hydrocarbon receptor mediates cytotoxicity of $\mathrm{PAH}$ and oxy-PAH}

The aryl hydrocarbon receptor (AhR) is a ligandactivated transcription factor that regulates biological responses to planar aromatic hydrocarbons and is known to act primarily as a sensor of xenobiotic chemicals [25, 26]. As shown in Fig. 6a, AhR translocated into the nucleus from the membrane in a time-dependent manner in cardiomyocytes treated with both forms of PAH. The amount of AhR translocated was significantly higher in cardiomyocytes treated with oxy-PAHs than in those treated with PAHs. In order to investigate whether the intracellular translocation of PAHs by AhR promotes calcium perturbation, we used AhR antagonists, $\alpha$ naphthoflavone $(\alpha-\mathrm{NF})$ or propranolol to block the cellular translocation of AhR. We observed that AhR translocation was successfully inhibited by $\alpha-\mathrm{NF}$ (Fig. 6b). Subsequently, decreased levels of phosphorylated CaMKII and RyR2 and increased SERCA2a levels were successfully rescued by treatment with $\alpha-N F$ or propranolol (Fig. 6c and d).

\section{Discussion}

Several studies have shown that there is an association between ambient air particles and cardiovascular dysfunction; however, the underlying mechanisms are complex and variable and remain to be elucidated [27]. In particular, the effects on the heart are acute and, therefore, frequently lethal, making it imperative that their mechanisms in the myocardium are identified. The present study demonstrated that PM exposure significantly increases ROS generation and calcium perturbation, leading to electrophysiological instability in cardiomyocytes. In addition, results obtained suggest that these instabilities are mainly induced by the oxy-PAHs contained in PM. Outcomes from chemical intervention by NAC support a role for ROS in mediating these effects. In the present study, significant electrophysiological alterations were observed a few minutes after PM exposure; they were greater in cardiomyocytes treated with WPM than in those treated with SPM and were markedly attenuated by the ROS scavenger, NAC. These results suggest that electrophysiological changes in cardiomyocytes are primarily mediated by ROS generation.

Even though the mechanisms by which air pollutants influence the risk of cardiovascular events are still under investigation, there are several plausible theories [28]. After PM penetration beyond the upper respiratory tract into the parenchymal region of the lung [29], the lung releases pro-oxidative (i.e., ROS) and proinflammatory (i.e., cytokines, such as IL-6 and TNF- $\alpha$ ) mediator and 

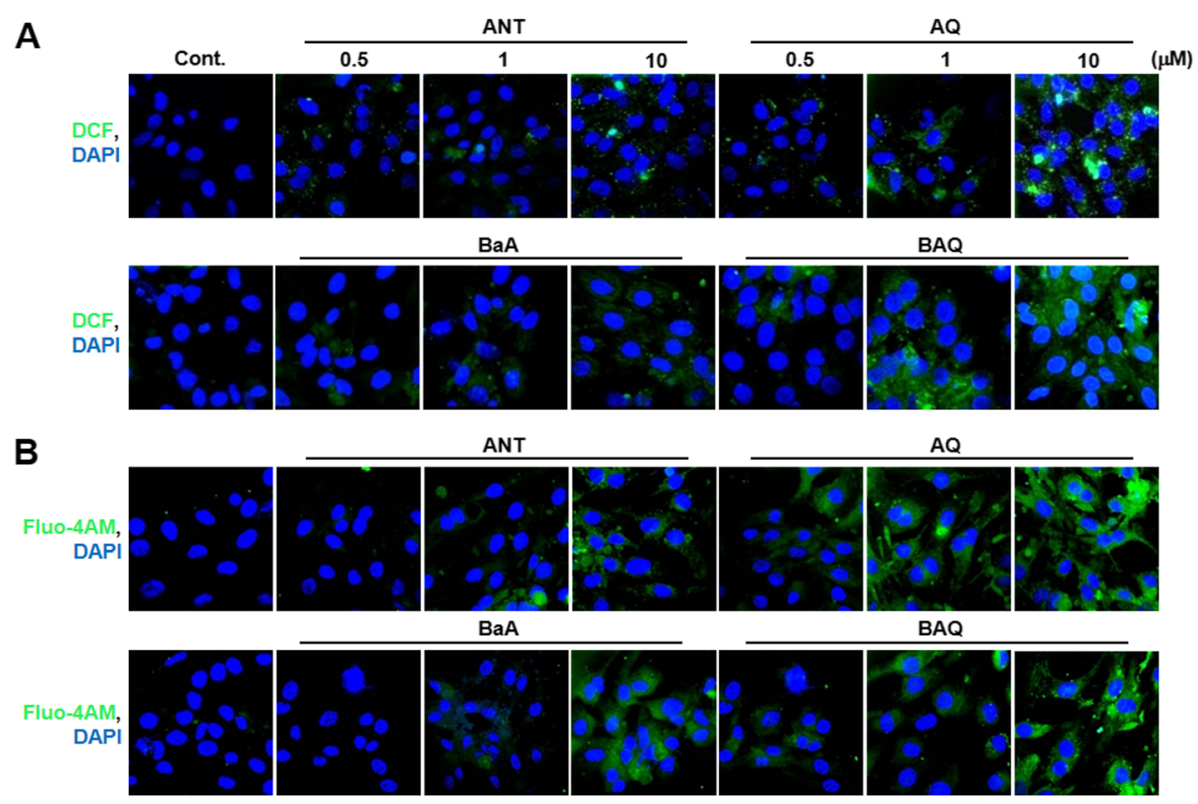

C

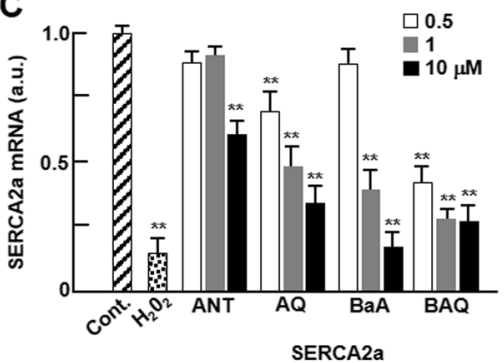

D
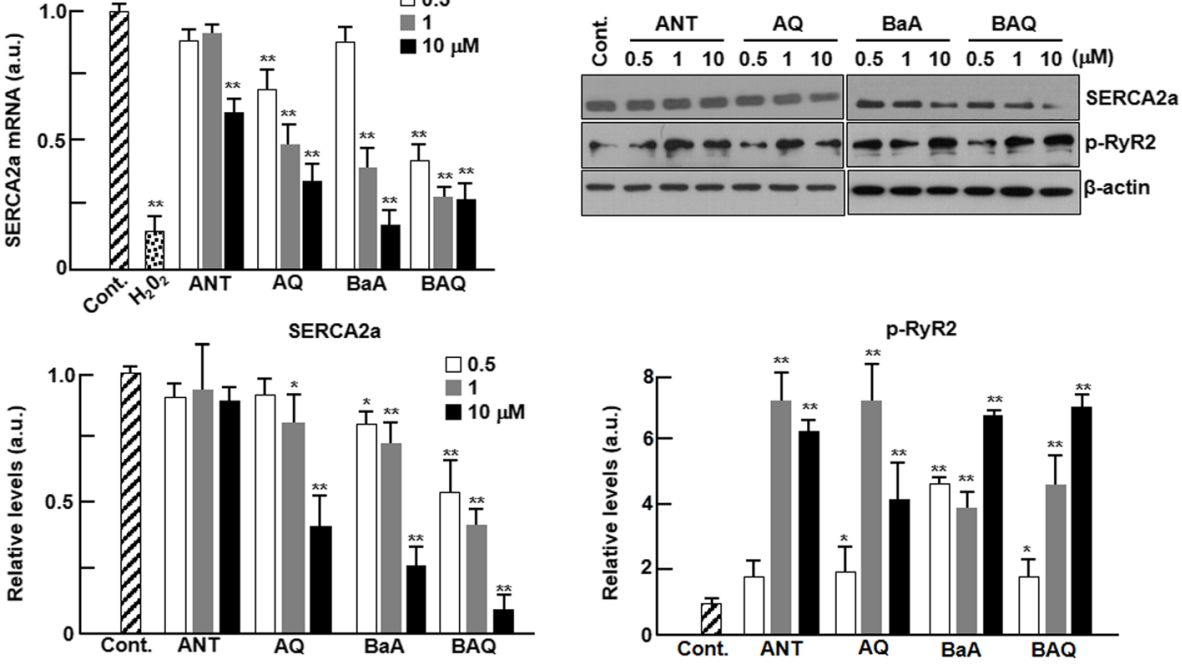

Fig. 4 Effect of PAH and oxy-PAH on ROS generation and $\mathrm{Ca}^{2+}$ perturbation. Cardiomyocytes were treated with control (DMSO), ANT, AQ, BaA, or $\mathrm{BAQ}$ at the indicated concentrations and analyzed for ROS generation, intracellular $\mathrm{Ca}^{2+}$ levels, and expression of $\mathrm{Ca}^{2+}$-related genes.

Representative fluorescence images of cardiomyocytes loaded with (a) $\mathrm{H}_{2}$ DCF-DA (green) and (b) Fluo-4 AM (green) $(n=4)$. Nuclei were stained with DAPI (blue). (c) The mRNA levels of SERCA2a were quantified by qPCR $(n=4)$. Gene expression levels were normalized to $\mathrm{GAPDH}_{\mathrm{H}}$ and $\mathrm{H}_{2} \mathrm{O}_{2}$ $(200 \mathrm{nM})$ was used as a positive control. $\mathbf{d}$ The expression levels of phospho-CaMKIl and SERCA2a were analyzed by western blotting $(n=5)$. Protein levels were normalized to $\beta$-actin. All values are represented as mean $\pm \mathrm{SD}$. ${ }^{*} P<0.05$ or ${ }^{* *} P<0.01$ compared with control

vasoactive hormones, such as endothelins, both locally and into the systemic circulation [30-32]. These secreted molecules could be related to PM-induced alterations during the autonomic control of the heart [2,33], which are responsible for the occurrence of cardiovascular disease, especially arrhythmias. Indeed, some studies have shown that animals exposed to diesel exhaustion had reduced heart rate variability [34], and these experimental data are supported by several clinical studies that show a proportional relationship between PM concentration and heart rate variability $[35,36]$. Decreased heart rate variability indicates the existence of a state of cardiac autonomy dysfunction and is an obvious risk factor for sudden cardiac death due to arrhythmias [37]. The underlying mechanisms responsible for electrophysiological alterations remain unclear but might involve direct effects of PM or indirect effects of biochemical molecules secreted by PM on cardiac ion channels [38].

Ambient particulate matter is a complex mixture containing various types of organic matter, PAHs, and inorganic metals. Indeed, it has been known that the metal- 


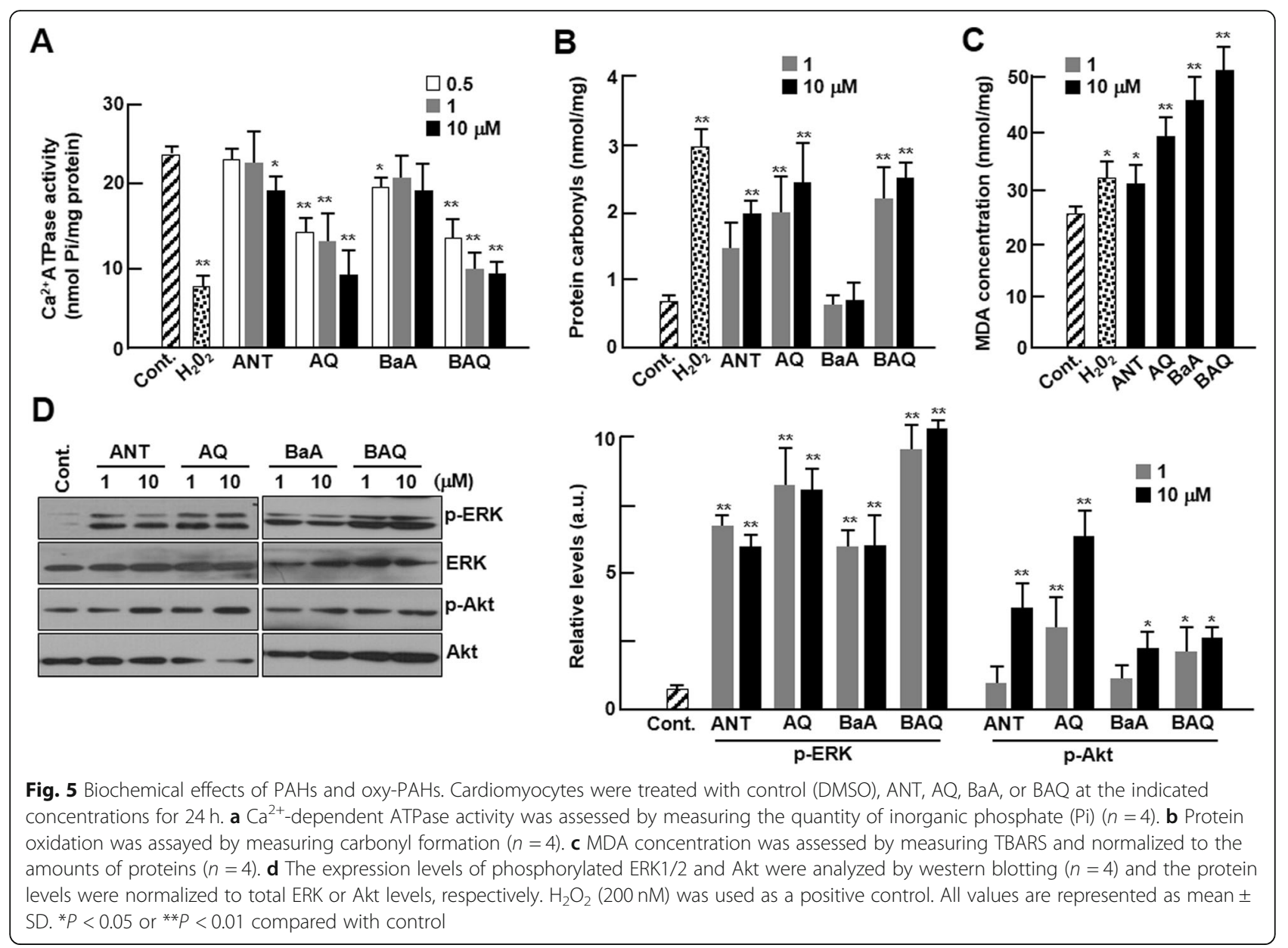

mediated generation of ROS can cause severe oxidative stress within cells or tissues through the oxidation of nucleic acids, proteins, and lipids [39, 40]. However, the main finding of this study is that arrhythmic parameters, such as resting membrane potential and amplitude, were significantly altered by PM treatment, and the degree of alteration was greater in WPM-treated cells, which contain more PAHs including oxy-PAHs. Furthermore, our results support the hypothesis that oxy-PAHs are more closely associated with a risk of cardiac arrhythmia than PAHs, because of the differential ROS generation. Indeed, there are some reports that the cardiac effects by DEP, especially arrhythmia, have been attributed to changes in autonomic activity that was not present in cells [41]. However, there are other recent data supporting our results that PM can cross into the pulmonary and systemic circulations directly affecting the heart and blood vessels [42] and DEP has shown both direct and indirect effects on cardiomyocyte functions [43]. The electrophysiological instability by PM or PAHs was completely blocked by pretreatment of the cells with an ROS scavenger, which is consistent with a recent study that revealed that the arrhythmogenic effects induced by
DEP were prevented by antioxidant treatment and a CaMKII blockade [9]. In addition, we showed that PM treatment subsequently disturbed calcium homeostasis in cardiomyocytes. The expression levels of representative calcium regulating proteins, such as CaMKII and RyR2, were significantly altered. Interestingly, SERCA2a expression significantly decreased only in WPM-treated cardiomyocytes, and the levels of NCX2 were higher in cardiomyocytes treated with WPM than in those treated with SPM. These results suggest that the specific components or their concentrations in WPM affect cardiomyocyte redox stress and calcium perturbation more than the components of SPM, which is consistent with the result that PAHs increase intracellular calcium in various cell types in a dose-dependent manner [44].

The main composition of PAHs, including oxy-PAHs in sampled PM, was determined in a previous study. However, it is not clear which constituents contributed to the observed adverse effects, as there is complexity of components and many unverified molecules, such as a variety of metals, biological compounds, and elemental carbons [12]. In addition, although there is accumulating evidence that PAHs play a critical role in the production 


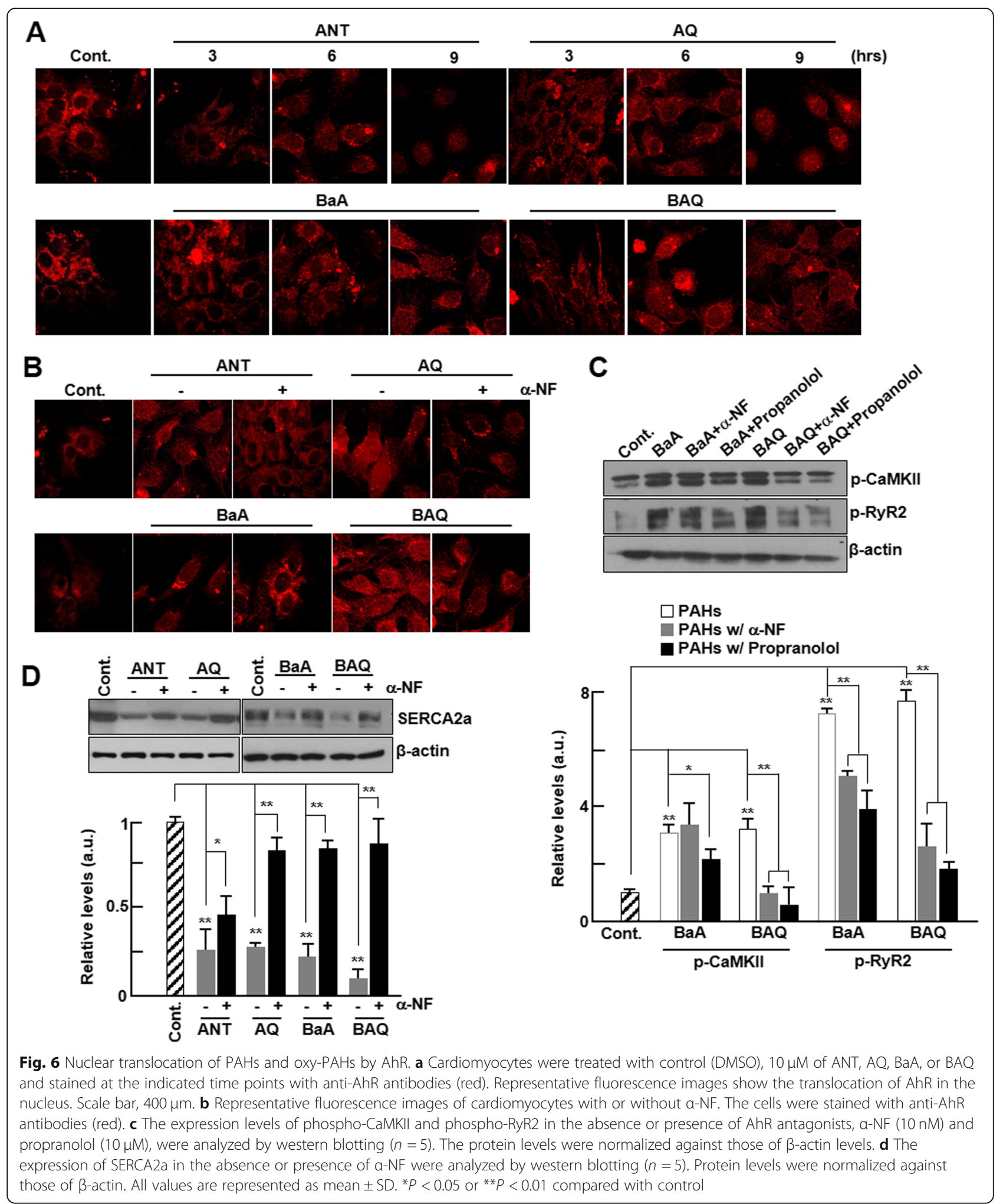

of oxidative stress, the differential effects between PAHs and oxy-PAHs have not been determined. The findings of this study show that exposure to oxy-PAHs induces more ROS and, subsequently, more electrophysiological instability than PAHs in cardiomyocytes. In addition, the effect on SERCA2a and RyR2 levels was significantly 
Table 3 Sequences of primers used for real-time quantitative PCR

\begin{tabular}{|c|c|}
\hline Gene & Primer sequence \\
\hline GAPDH & $\begin{array}{l}\text { Sense: 5'-CAGTGCCAGCCTCGTCTCAT-3' } \\
\text { Antisense: 5'-TGGTAACCAGGCGTCCGATA-3' }\end{array}$ \\
\hline SERCA2a & $\begin{array}{l}\text { Sense: 5'-CGAGTTGAACCTTCCCACAA-3' } \\
\text { Antisense: 5'-AGGAGATGAGGTAGCCGATGAA-3' }\end{array}$ \\
\hline RyR2 & $\begin{array}{l}\text { Sense: 5'-CAAACAGGGCAGAAGACACC-3' } \\
\text { Antisense: 5'-CTCTGAGGGTGCTCCACCT-3' }\end{array}$ \\
\hline CaMKII & $\begin{array}{l}\text { Sense: 5'-CATCCTGAACCCTCACATCCA-3' } \\
\text { Antisense: 5'-CCGCATCCAGGTACTGAGAGTGAT-3' }\end{array}$ \\
\hline Calsequestrin2 & $\begin{array}{l}\text { Sense: 5'-TCAAAGACCCACCCTACGTC-3' } \\
\text { Antisense: 5'-AGTCGTCTGGGTCAATCCAC-3' }\end{array}$ \\
\hline CalcineurinA & $\begin{array}{l}\text { Sense: 5'-TGGTGAAAGCCGTTCCATTT-3' } \\
\text { Antisense: 5' CCCATCGTTATCAAACACTTCCT-3' }\end{array}$ \\
\hline Calmodulin & $\begin{array}{l}\text { Sense: 5'-GGCATCCTGCTTTAGCCTGAG-3' } \\
\text { Antisense: 5'-ACATGCTATCCCTCTCGTGTGAC-3' }\end{array}$ \\
\hline NCX1 & $\begin{array}{l}\text { Sense: 5'-AGCAAGGCGGCTTCTCTITT-3' } \\
\text { Antisense: 5'-GCTGGTCTGTCTCCTTCATGT-3' }\end{array}$ \\
\hline $\mathrm{NCX} 2$ & $\begin{array}{l}\text { Sense: 5'-CACTACGAGGATGCTTGTGG-3' } \\
\text { Antisense: 5'-CCTTCTTCTCATACTCTTCGT-3' }\end{array}$ \\
\hline NCX3 & $\begin{array}{l}\text { Sense: 5'-CCTGTGGCTCCTCTACGTACTCTT-3' } \\
\text { Antisense: 5'-GAGGTCTTGTTCTGGTGGTTCA-3' }\end{array}$ \\
\hline
\end{tabular}

greater in cardiomyocytes treated with oxy-PAHs than in those treated with PAHs, and the effects were suppressed by the ROS scavenger NAC.

As mentioned above, we analyzed the concentrations of other various constituents including organic carbons (OC), elemental carbons (EC), dicarboxylic acids, and metals in seasonal PM10 samples and found that the concentrations of these constituents were not displying any significant differences between SPM and WPM (data not shown). Therefore, we concluded that the differentially induced electrophysiological instability by PM was mainly through PAHs, especially oxy-PAHs, in winter samples. Furthermore, oxy-PAHs entered the cells more rapidly than PAHs, then these molecules translocated into the nucleus through AhR. Also, the expression levels of AhR is about 2-10 fold higher in cardiac than in other tissues of mice; subsequently, expression of the target gene, CYP1A1, increased by $\sim 10$ fold in cardiac tissues compared to that in other tissues in BaP-treated mice [45]. This demonstrates that the electrophysiological instability induced by oxy-PAHs might be specific to the myocardium. Our results concur with previous results which showed that $\mathrm{BaP}$ enters cells via AhR, resulting in redox stress and c-Ha-ras activation in vascular smooth muscle cells, which was prevented by the ROS scavenger NAC [46]. However, the redox stress between $\mathrm{BaP}$ and $\mathrm{BaP}-3,6$-quinone (BaPQ), an oxygenated derivative of $\mathrm{BaP}$, was not evaluated in this study. Our result are also supported by several previous reports that 9,10-phenanthrenequinone, one of the major components of PM can cause an impairment of endothelium-dependent vasorelaxation through the regulation of eNOS activity and are associated with cardiopulmonary diseases $[47,48]$.

The present study has some methodological limitations. One of the drawbacks is the direct effect of PAHs on electrophysiological instability was revealed in cells rather than in whole heart or animal models. Therefore, the consequences of PM or PAHs treatment reported herein may not manifest in humans after real-world inhalation. Secondly, the concentrations of individual PAHs used in this study was slightly higher than the concentration of mobilized PAHs from PM. Although there is a previously reported association between highpollution days and the increased incidence of acute cardiovascular events [49], further investigation for the association between the mobilized constituents and their concentration and induction of electrophysiological instability will be needed. Even though there are limitations as shown above for this study, our results of the effects of PAHs, especially oxy-PAHs, on electrophysiological instability in cardiomyocytes might be expanded to the area of mammalian cardiotoxicity. Indeed, highthroughput in in vitro cardiotoxicity of 69 environmental chemicals was successfully assessed using human induced pluripotent stem cell-derived cardiomyocytes [50].

\section{Conclusions}

Our results provide strong evidence that ambient PM increases arrhythmia by ROS generation, and oxy-PAHs are the key components of PM in this regard. Electrophysiological instability and subsequent calcium perturbation by PM or PAHs were successfully attenuated by an ROS scavenger. The adverse effects of oxy-PAHs, which are mediated by AhR, are more severe than those of PAHs. AhR is highly abundant in cardiac tissue, making the arrhythmogenicity of oxy-PAHs particularly hazardous. Although there is an increasing amount of clinical evidence supporting our findings of cardiac electrophysiological instability by ambient PM, the in vivo and clinical relevance of these findings further remains to be elucidated.

\section{Methods}

\section{Ambient particulate matters and preparation of organic components}

Collection of ambient particulate matter (PM) at the Seoul metropolitan area and particle preparation was described in a previous study [51] which showed the detailed process for sampling of PM10 and extraction of organic matter from PM. Briefly, PM10 samples were collected at the roof of a public health building of Seoul National University in the Seoul metropolitan area. The sampling site is surrounded by commercial and residential areas of the city. PM10 samples were collected on 
quartz fiber filters (QFFs) $\left(20.3 \times 25.4 \mathrm{~cm}^{2}\right)$ for $24 \mathrm{~h}$ in summer (June-August) and winter (December-February). After sampling, the filter was wrapped in pre-baked aluminum foils and stored in a freezer $\left(-20^{\circ} \mathrm{C}\right)$ until analysis. The filter was extracted by sonication with a mixture of dichloromethane (DCM) and methanol (3:1, $v / v)$ for $30 \mathrm{~min}$. Extracts were evaporated under a stream of $\mathrm{N}_{2}$ gas (Zymark Turbo Vap II) down to a volume of $10 \mathrm{~mL}$ and then was filtered using a $0.45 \mu \mathrm{m}$ syringe filter. For further usage, the extracts were diluted 10-fold with dimethylsulfoxide (DMSO). The analyzed organic compounds including PAHs and oxy-PAHs and their concentrations were presented in Table 1.

\section{Cell culture and treatments}

Neonatal rat cardiomyocytes were isolated and purified by modifying previously described methods [52]. Briefly, 2-3 day old Sprague-Dawley rat pups were disinfected with povidone and then dissected. The chests of these rats were opened and their hearts were rapidly removed and washed with the Phosphate-buffered saline solution (pH 7.2, WelGENE) lacking $\mathrm{Ca}^{2+}$ and $\mathrm{Mg}^{2+}$. Using micro-dissecting scissors, hearts were minced until the pieces were approximately $1 \mathrm{~mm}^{3}$ and treated with $5 \mathrm{~mL}$ of collagenase type II $(0.9 \mathrm{mg} / \mathrm{mL}, 210$ units $/ \mathrm{mg}$, Gibco $\mathrm{BRL}$ ) for $7 \mathrm{~min}$ at room temperature. The cells in the supernatant were transferred to a tube containing cell culture medium ( $\alpha$-MEM containing 10\% fetal bovine serum, WelGENE). The tubes were centrifuged at 1200 rpm for $4 \mathrm{~min}$ at room temperature, and the cell pellets were resuspended in $3 \mathrm{~mL}$ of cell culture medium. The above procedures were repeated 6-8 times until only a little tissue was left. Cell suspensions were washed twice with cell culture medium and seeded to achieve a final concentration of $5 \times 10^{5}$ cells $/ \mathrm{mL}$ and then they were plated onto gelatin-coated 6-well plates. The cells were cultured in $\alpha$-MEM containing $10 \%$ fetal bovine serum with $0.1 \mathrm{mM}$ bromodeoxyuridine (BrdU), which was used to prevent proliferation of cardiac fibroblasts. Cells were then cultured in $5 \% \mathrm{CO}_{2}$ incubator at $37^{\circ} \mathrm{C}$. The cells were then treated with designated volumes of PM extracts mentioned above and DMSO $(0.1 \%$ of final concentration) is used as a control treatment.

\section{Patch-clamp recordings}

The cells were bathed in external solution containing $(\mathrm{mM}): \mathrm{NaCl} 135, \mathrm{KCl} 5.4, \mathrm{MgCl}_{2}$ 1.0, $\mathrm{CaCl}_{2} 1.8$, $\mathrm{NaH}_{2} \mathrm{PO}_{4} 0.33$, glucose 5, and HEPES 10 and was adjusted to $\mathrm{pH} 7.4$ with Tris buffer. The pipetted solution contained (in mM): Mg-ATP 3, CsCl 140, HEPES 10 and EGTA 10 and was adjusted to $\mathrm{pH} 7.2$ with Tris buffer. Currents or potentials were amplified using an Axopatch 200B (Axon Instruments) and digitized with a 16bit analog to digital converter (Digidata 1550A; Axon
Instruments). The data were filtered at $5 \mathrm{kHz}$ and was displayed on a computer monitor. Results were analyzed using pClamp software (version 9.2; Axon Instruments) and GraphPad Prism software. All experiments were performed at $30^{\circ} \mathrm{C}$.

\section{Measurement of intracellular reactive oxygen species (ROS)} Intracellular ROS were measured using a fluorescent dye technique. Cardiomyocytes were seeded onto a 24-well plate with glass cover slips at a density of $5 \times 10^{4}$ cells/ $\mathrm{mL}$ and cultured for $24 \mathrm{~h}$. Then, the cells were treated with a negative control (DMSO), positive control (200 $\mathrm{nM}$ of $\mathrm{H}_{2} \mathrm{O}_{2}$ ), SPM, and WPM in a dose dependent manner for $1 \mathrm{~h}$. Then, the cells were washed twice with calcium free PBS (PBSc) and loaded with 2',7'-dichlorofluorescin diacetate $\left(\mathrm{H}_{2} \mathrm{DCF}-\mathrm{DA}\right.$, Invitrogen, USA) and $4^{\prime}$, 6-diamidino-2-phenylindole (DAPI) diluted with calcium free warm PBS to a final concentration of $10 \mu \mathrm{M}$ and $50 \mu \mathrm{g} / \mathrm{mL}$, respectively. Then, the cells were incubated for $10 \mathrm{~min}$ at $37^{\circ} \mathrm{C}$ in the dark. The probe $\mathrm{H}_{2}$ DCF-DA $(10 \mu \mathrm{M})$ entered into the cells, and the acetate groups on $\mathrm{H}_{2} \mathrm{DCF}$ DA were cleaved by cellular esterases, trapping the nonfluorescent $2^{\prime}, 7^{\prime}$-dichlorofluorescin (DCFH) within the cells. Subsequent oxidation by reactive oxygen species yielded a fluorescent product DCF. Then, the cells were gently washed under the coverslips three times in warm PBS and the coverslips were placed in the chamber, which was mounted on the stage of an inverted microscope equipped with a confocal laser-scanning system. The dye, when exposed to an excitation wavelength of $480 \mathrm{~nm}$, emitted light at $535 \mathrm{~nm}$ only when it had been oxidized. Fluorescence images were collected using a confocal microscope (Fluoview FV1000 confocal system, Olympus) by excitation at $488 \mathrm{~nm}$ and emission greater than $500 \mathrm{~nm}$ with a long-pass barrier filter. The fluorescence intensity of an equivalent field size $(3 \times 3 \mathrm{~mm})$ in a plate was measured using Image J quantification software.

\section{Measurement of intracellular calcium levels}

The intracellular calcium was measured using a fluorescent calcium indicator, Fluo-4 AM (Invitrogen). Cardiomyocytes were seeded onto a 4-well chamber at a density of $1 \times 10^{5}$ cells $/ \mathrm{mL}$ and cultured for $24 \mathrm{~h}$. Then, the cells were treated a negative control (DMSO), SPM, and WPM in a dose dependent manner for $20 \mathrm{~min}$. The cells were then washed with a serum free medium $(\alpha-$ MEM, WelGENE) and loaded with Fluo-4 AM diluted with serum free medium to a final concentration of $2 \mu \mathrm{M}$ and incubated for $20 \mathrm{~min}$ at $37^{\circ} \mathrm{C}$ in the dark. Then, the cells were washed twice with warm PBS buffer and covered with a cover slip. Fluo- 4 AM fluorescence imaging was performed using a confocal microscope (Fluoview FV1000 confocal system, Olympus). Fluo-4 
AM was excited with the laser at $488 \mathrm{~nm}$, and fluorescence was measured at a wavelength of $515 \mathrm{~nm}$.

\section{Immunocytochemistry}

Cardiomyocytes were cultured onto a 24-well plate with glass cover slips at a density of $5 \times 10^{4}$ cells/well. The cells were then fixed with $4 \%$ paraformaldehyde for $20 \mathrm{~min}$ and quenched with $1 \mathrm{M}$ ethanolamine diluted in PBSc. After washing, cells were blocked with $0.5 \%$ bovine serum albumin in PBS for $30 \mathrm{~min}$, then the blocking solution was removed and the cells were incubated overnight at $4{ }^{\circ} \mathrm{C}$ with rabbit anti-AhR (1:100 dilutions, BioWorld). Cells were washed and incubated with mouse anti-rabbit IgG-TR (1: 1000 dilutions, Santa Cruz Biotechnology) at room temperature for $1 \mathrm{~h}$. Then, the cells were gently washed under the cover slip three times with PBS and visualized under a laser scanning confocal microscope (Fluoview FV1000 confocal system, Olympus).

\section{Protein carbonylation colorimetric assay}

Cardiomyocytes were exposed to PAH and oxy-PAH for $24 \mathrm{~h}$. Each serum was centrifuged at $14,000 \mathrm{rpm}$ for 10 min to eliminate all particulate matter that might interfere with this reaction. Then, a solution of $10 \mathrm{mM}$ 2,4-dinitrophenylhydrazine $(\mathrm{DNPH})$ in $2 \mathrm{~N} \mathrm{HCl}$ was added to the serum containing protein $(1 \mathrm{mg} / \mathrm{mL})$ of each sample, incubate for $45 \mathrm{~min}$ at room temperature in the dark with occasional mixing. A blank reagent protein sample that reacted with $2 \mathrm{~N} \mathrm{HCl}$ was added to each sample. Then, with $20 \%$ trichloroacetic acid (TCA) was added to each samples and centrifuged for $10 \mathrm{~min}$ on ice. The supernatants was discarded, and protein pellets were washed 5 times with $1 \mathrm{~mL}$ of ethanol/ethyl acetate $(1: 1, v / v)$ to remove any free DNPH. After the final washing step, samples were resuspended in $6 \mathrm{M}$ guanidine hydrochloride, which is a protein solubilization solution, and vortexed thoroughly and incubated at $37^{\circ} \mathrm{C}$ for $10 \mathrm{~min}$. Then, the samples were centrifuged at $14,000 \mathrm{rpm}$ for $10 \mathrm{~min}$ to remove any debris. To determine the protein concentrations of the solubilized protein sample, Bradford protein assay (Bio-Rad, Hercules) was performed. Carbonyl contents are determined from the absorbance measured at $375 \mathrm{~nm}$ against the blank for each sample using a molar absorption coefficient of $22,000 \mathrm{M}^{-1} \mathrm{~cm}^{-1}$.

\section{Lipid peroxidation (MDA) assay}

The amount of lipid peroxidation was estimated by measuring the amounts of thiobarbituric acid-reactive substances (TBARS). Briefly, samples were incubated with $0.5 \%$ TBA in $20 \%$ acetic acid solution ( $\mathrm{pH} 3.7$ ). After incubation at $95{ }^{\circ} \mathrm{C}$ for $40 \mathrm{~min}$, the samples were kept on ice, and then centrifuged at $4000 \mathrm{rpm}$ for 10 min. TBARS contents were determined by measuring absorbance at $532 \mathrm{~nm}$. TBARS values were calculated by using a malondialdehyde (MDA) standard curve. Results were expressed as nmol MDA/mg protein.

\section{Cardiomyocyte microsomes preparation and $\mathrm{Ca}^{2+}$-ATPase activity assay}

Cardiomyocytes were harvested, washed twice in $0.9 \%$ $\mathrm{NaCl}$. Then, the cells were resuspended and incubated with lysis buffer $\left(10 \mathrm{mM}\right.$ Tris, $\mathrm{pH} 7.5$ and $\left.0.5 \mathrm{mM} \mathrm{MgCl}_{2}\right)$ on ice for $10 \mathrm{~min}$ and then $0.1 \mathrm{mM}$ phenylmethanesulfonylfluoride (PMSF) was added. After lysis, the cells were homogenized with a disposable homogenizer (BioMasher), and then a solution containing $0.5 \mathrm{M}$ sucrose, $10 \mathrm{mM}$ Tris ( $\mathrm{pH} 7.5$ ), $40 \mu \mathrm{M} \mathrm{CaCl}, 6 \mathrm{mM} \beta-\mathrm{ME}$ and $0.3 \mathrm{M} \mathrm{KCl}$ was added, and the cells were homogenized for an additional lysis step. The cell homogenate was then centrifuged at 14,000 rpm for 20 min. The supernatant solutions were then transferred to another ultracentrifuge tube containing $2.5 \mathrm{M} \mathrm{KCl}$ and centrifuged at 90,000 rpm for $1 \mathrm{~h}$. The pellets were washed and resuspended with wash buffer $(0.25 \mathrm{M}$ sucrose, $10 \mathrm{mM}$ Tris (pH 7.5), $20 \mu \mathrm{M} \mathrm{CaCl}, 3 \mathrm{mM} \beta-\mathrm{ME}, 0.15 \mathrm{M} \mathrm{KCl}$ ), and the protein concentrations were determined using Bradford protein assay. $\mathrm{Ca}^{2+}$-ATPase activity was determined by measuring the quantity of inorganic phosphate $(\mathrm{Pi})$ liberated from the hydrolysis of ATP by colorimetric assay. The microsome membranes (SERCA2a $30 \mu \mathrm{g} / \mathrm{mL}$ ) were incubated with the reaction buffer (50 mM MOPS, $100 \mathrm{mM}$ $\mathrm{KCl}, 5 \mathrm{mM} \mathrm{MgCl}_{2}, \mathrm{NaN}_{3}, 1 \mathrm{mM}$ EGTA and $1 \mathrm{mM} \mathrm{CaCl}$ $\mathrm{pH}$ 7.0) for $10 \mathrm{~min}$, and $10 \mathrm{mM}$ ATP (final concentration, $1 \mathrm{mM}$ ) was added. After $30 \mathrm{~min}$ of incubation, the reaction mixture was measured by a Malachite green phosphate assay kit (BioAssay Systems). The absorbance of the resulting colored complex was determined at $620 \mathrm{~nm}$. The quantity of $\mathrm{Pi}$ was calculated by using a phosphate $\left(\mathrm{KH}_{2} \mathrm{PO}_{4}\right)$ standard curve.

\section{Real-time quantitative PCR (qPCR)}

The expression levels of various genes were analyzed by a qPCR assay. The cells were seeded into a 6-well plate with glass cover slips at a density of $5 \times 10^{5}$ cells $/ \mathrm{mL}$ and cultured for $24 \mathrm{~h}$. The cells were treated with either negative control (DMSO), SPM, or WPM in a dose dependent manner for $12 \mathrm{~h}$. Total RNA was extracted using TRIzol lysis reagent (QIAGEN) according to the instructions provided by the manufacturer. The total RNA concentration of each sample was measured by a spectrophotometer (Eppendorf) at $260 \mathrm{~nm}$. Total RNA was subjected to reverse transcription using HelixCript ${ }^{\mathrm{TM}}$ 1st-Strand cDNA Synthesis Kit (NanoHelix). Real-time quantitative PCR with realHelix ${ }^{\mathrm{TM}}$ qPCR kit (NanoHelix) was performed by the SYBR Green method using an Applied Rotor-Gene $3000^{\mathrm{Tm}}$. Gene expression was normalized to GAPDH. The relative mRNA expression levels were quantified and analyzed using Rotor-Gene 6 
software (Corbett-research) using ${ }^{\triangle \Delta} \mathrm{Ct}$ methods. Table 3 shows all the primer sequences used for qPCR.

\section{Immunoblot analysis}

Cardiomyocytes were seeded onto a 6-well plate at a density of $5 \times 10^{5}$ cells $/ \mathrm{mL}$ and cultured for $24 \mathrm{~h}$. Cells were then treated with either negative control (DMSO), PAHs, or oxy-PAHs in dose dependent manner for $24 \mathrm{~h}$. The cells were then washed once in PBS buffer and lysed in RIPA buffer containing PMSF and phosphatase inhibitor. The protein concentrations were determined using the Bradford protein Assay. Proteins were separated in a 6-10\% sodium dodecyl sulfate-polyacrylamide gel and transferred to a polyvinylidiene difluoride membrane (BioRad laboratories, Inc.). After blocking the membranes with Tris-buffered saline-Tween 20 (TBS-T, 0.1\% Tween 20) containing $5 \%$ skim milk for $1 \mathrm{~h}$ at room temperature, the membranes were incubated with a primary antibody for overnight at $4{ }^{\circ} \mathrm{C}$. The primary antibodies were used at the following dilutions in blocking buffer: phospho Akt (1:200, \#9271, Cell Signaling Technology), Akt (1:1000, \#9297, Cell Signaling Technology), phospho ERK (1:1000, \#9101, Cell Signaling Technology), ERK (1:1000, SC-135900, Santa Cruz), $\beta$-actin (1:5000, Sigma), CaMKll (1:500, LFPA20064, AbFRONTIER), p-CaMK1l (1:500, LF-PA20065, AbFRONTIER), ATP2A2/SERCA2 (1:5000, Cell Signaling Technology), RYR2 (1:500, 19,765-1-AP, Proteintech Group) and p-S2808 RYR2 (1:500, ab59225, Abcam). The membrane was washed five times with TBS-T for $5 \mathrm{~min}$ and incubated for $1 \mathrm{~h}$ at room temperature with secondary antibodies. After extensive washing, bands were detected by an enhanced chemiluminescence reagent (ECL, BIONOTE, Animal Genetics Inc.). The band intensities were quantified using the Image J quantification software.

\section{Statistical analysis}

All quantified data from at least triplicate measurements were analyzed with SPSS 13.0 software. Data are expressed as mean \pm SD. Statistical comparisons between two groups were performed using the Student's t-test. Statistical comparisons among multiple groups were performed using analysis of variance (ANOVA). A twotailed $P<0.05$ was considered statistically significant.

\section{Acknowledgements}

Not applicable.

\section{Authors' contributions}

SJ, LL, DHC, YJK, and HS designed the experiments and contributed to data analysis and interpretation. SJ and LL performed most of the experimental work. HYJ and SC, and JYJ performed electrophysiological alterations measurements. JYL prepared and analyzed the organic components from PM. SJ and LL wrote the initial draft of the manuscript. DHC and HS were also major contributors in writing the manuscript. All the authors read and approved the final manuscript.

\section{Funding}

This work was supported by the Basic Science Research Program through the National Research Foundation of Korea (NRF) funded by the Ministry of Science, ICT and future Planning, Grant/Award number: 2019R1A2C1088144 and a grant from the Chosun University (2018)

\section{Availability of data and materials}

The datasets used and/or analyzed during the current study are available from the corresponding author on reasonable request.

\section{Ethics approval and consent to participate}

Not applicable.

\section{Consent for publication}

Not applicable.

\section{Competing interests}

The authors declare that they have no competing interests.

\section{Author details}

'Department of Biomaterials, Chosun University Graduate School, Gwangju 61452, South Korea. ${ }^{2}$ Cancer mutation Research Center, Chosun University, Gwangju 61452, South Korea. ${ }^{3}$ Department of Physiology, Chosun University School of Medicine, Gwangju 61452, South Korea. ${ }^{4}$ Department of Internal Medicine, Chosun University School of Medicine, Gwangju 61452, South Korea. ${ }^{5}$ Department of Environmental Science and Engineerings, Ewha Womans University, Seoul 03760, South Korea. ${ }^{6}$ Department of Biochemistry and Molecular Biology, Chosun University School of Medicine, Gwangju 61452, South Korea.

Received: 26 December 2019 Accepted: 12 May 2020

Published online: 11 June 2020

\section{References}

1. Dockery DW, Pope CA 3rd, Xu X, Spengler JD, Ware JH, Fay ME, et al. An association between air pollution and mortality in six U.S. cities. N Engl J Med. 1993;329(24):1753-9. https://doi.org/10.1056/NEJM199312093292401 https://www.ncbi.nlm.nih.gov/pubmed/8179653.

2. Brook RD, Rajagopalan S, Pope CA 3rd, Brook JR, Bhatnagar A, Diez-Roux AV, et al. Particulate matter air pollution and cardiovascular disease: An update to the scientific statement from the American Heart Association. Circulation. 2010;121(21):2331-78. https://doi.org/10.1161/CIR.0b013e3181dbece1 https://www.ncbi.nlm.nih.gov/pubmed/20458016.

3. Stockfelt L, Andersson EM, Molnar P, Gidhagen L, Segersson D, Rosengren A, et al. Long-term effects of total and source-specific particulate air pollution on incident cardiovascular disease in Gothenburg, Sweden. Environ Res. 2017;158:61-71. https://doi.org/10.1016/j.envres.2017.05.036 https://www.ncbi.nlm.nih.gov/pubmed/28600978.

4. Du Y, Xu X, Chu M, Guo Y, Wang J. Air particulate matter and cardiovascular disease: the epidemiological, biomedical and clinical evidence. J Thorac Dis. 2016;8(1):E8-E19. https://doi.org/10.3978/j.issn.2072-1439.2015.11.37 https:// www.ncbi.nlm.nih.gov/pubmed/26904258.

5. Hoek $G$, Brunekreef $B$, Fischer $P$, van Wijnen J. The association between air pollution and heart failure, arrhythmia, embolism, thrombosis, and other cardiovascular causes of death in a time series study. Epidemiology. 2001; 12(3):355-7 https://www.ncbi.nlm.nih.gov/pubmed/11337606.

6. Ljungman PL, Berglind N, Holmgren C, Gadler F, Edvardsson N, Pershagen $\mathrm{G}$, et al. Rapid effects of air pollution on ventricular arrhythmias. Eur Heart J. 2008;29(23):2894-901. https://doi.org/10.1093/eurheartj/ehn463 https:// www.ncbi.nlm.nih.gov/pubmed/19004842.

7. Kettunen J, Lanki T, Tiittanen P, Aalto PP, Koskentalo T, Kulmala M, et al. Associations of fine and ultrafine particulate air pollution with stroke mortality in an area of low air pollution levels. Stroke. 2007;38(3):918-22. https://doi.org/10.1161/01.STR.0000257999.49706.3b https://www.ncbi.nlm. nih.gov/pubmed/17303767.

8. Dales RE, Cakmak S, Vidal CB. Air pollution and hospitalization for venous thromboembolic disease in Chile. J Thromb Haemost. 2010;8(4):669-74. https://doi.org/10.1111/j.1538-7836.2010.03760.x https://www.ncbi.nlm.nih. gov/pubmed/20088925.

9. Kim JB, Kim C Choi E, Park S, Park H, Pak HN et al. Particulate air pollution induces arrhythmia via oxidative stress and calcium calmodulin kinase ॥ 
activation. Toxicol Appl Pharmacol. 2012;259(1):66-73. https://doi.org/10. 1016/.ttaap.2011.12.007 https://www.ncbi.nlm.nih.gov/pubmed/22197715.

10. Ghelfi E, Rhoden CR, Wellenius GA, Lawrence J, Gonzalez-Flecha B. Cardiac oxidative stress and electrophysiological changes in rats exposed to concentrated ambient particles are mediated by TRP-dependent pulmonary reflexes. Toxicol Sci. 2008;102(2):328-36. https://doi.org/10.1093/toxsci/ kfn005 https://www.ncbi.nlm.nih.gov/pubmed/18184637.

11. Hazari MS, Haykal-Coates N, Winsett DW, Krantz QT, King C, Costa DL, et al. TRPA1 and sympathetic activation contribute to increased risk of triggered cardiac arrhythmias in hypertensive rats exposed to diesel exhaust. Environ Health Perspect. 2011;119(7):951-7. https://doi.org/10.1289/ehp.1003200 https://www.ncbi.nlm.nih.gov/pubmed/21377951.

12. Song HS, Bang WG, Chung N, Cho YS, Kim YS, Cho MH. Effect of chelators and reductants on the mobilization of metals from ambient particulate matter. Environ Sci Technol. 2003:37(16):3531-6. https://doi.org/10.1021/ es025981p https://www.ncbi.nlm.nih.gov/pubmed/12953862.

13. Poursafa P, Moosazadeh M, Abedini E, Hajizadeh Y, Mansourian M, Pourzamani $\mathrm{H}$, et al. A systematic review on the effects of polycyclic aromatic hydrocarbons on Cardiometabolic impairment. Int J Prev Med. 2017;8:19. https://doi.org/10.4103/ijpvm.JJPVM_144_17 https://www.ncbi. nlm.nih.gov/pubmed/28479961.

14. Brucker N, Charao MF, Moro AM, Ferrari P, Bubols G, Sauer E, et al. Atherosclerotic process in taxi drivers occupationally exposed to air pollution and co-morbidities. Environ Res. 2014;131:31-8. https://doi.org/10. 1016/..envres.2014.02.012 https://www.ncbi.nlm.nih.gov/pubmed/24637182.

15. Niu X, Ho SSH, Ho KF, Huang Y, Sun J, Wang Q, et al. Atmospheric levels and cytotoxicity of polycyclic aromatic hydrocarbons and oxygenated-PAHs in PM2.5 in the Beijing-Tianjin-Hebei region. Environ Pollut. 2017;231(Pt 1): 1075-84. https://doi.org/10.1016/j.envpol.2017.08.099 https://www.ncbi.nlm. nih.gov/pubmed/28922714.

16. Simoneit BR, Medeiros PM, Didyk BM. Combustion products of plastics as indicators for refuse burning in the atmosphere. Environ Sci Technol. 2005; 39(18):6961-70 https://www.ncbi.nlm.nih.gov/pubmed/16201617.

17. Zielinska B, Sagebiel J, McDonald JD, Whitney K, Lawson DR. Emission rates and comparative chemical composition from selected in-use diesel and gasoline-fueled vehicles. J Air Waste Manag Assoc. 2004;54(9):1138-50 https://www.ncbi.nlm.nih.gov/pubmed/15468666.

18. Wang L, Atkinson R, Arey J. Formation of 9,10-phenanthrenequinone by atmospheric gas-phase reactions of phenanthrene. Atmos Environ. 2007 41(10):2025-35. https://doi.org/10.1016/j.atmosenv.2006.11.008 http://www. sciencedirect.com/science/article/pii/S1352231006011095.

19. Barbas JT, Sigman ME, Dabestani R. Photochemical oxidation of Phenanthrene Sorbed on silica gel. Environ Sci Technol. 1996;30(5):1776-80. https://doi.org/10.1021/es950769p https://doi.org/10.1021/es950769p.

20. Okona-Mensah KB, Battershill J, Boobis A, Fielder R. An approach to investigating the importance of high potency polycyclic aromatic hydrocarbons (PAHs) in the induction of lung cancer by air pollution. Food Chem Toxicol. 2005;43(7):1103-16. https://doi.org/10.1016/j.fct.2005.03.001 https://www.ncbi.nlm.nih.gov/pubmed/15833386.

21. Pedersen DU, Durant JL, Penman BW, Crespi CL, Hemond HF, Lafleur AL, et al. Human-cell mutagens in respirable airborne particles in the northeastern United States. 1. Mutagenicity of fractionated samples. Environ Sci Technol. 2004;38(3):682-9 https://www.ncbi.nlm.nih.gov/pubmed/1496 8851.

22. Bers DM. Cardiac excitation-contraction coupling. Nature. 2002;415(6868): 198-205. https://doi.org/10.1038/415198a.

23. Dalle-Donne I, Rossi R, Giustarini D, Milzani A, Colombo R. Protein carbonyl groups as biomarkers of oxidative stress. Clin Chim Acta. 2003;329(1-2):2338.

24. Gawel S, Wardas M, Niedworok E, Wardas P. Malondialdehyde (MDA) as a lipid peroxidation marker. Wiad Lek (Warsaw, Poland : 1960). 2004;57(9-10): 453-5.

25. Kawajiri K, Fujii-Kuriyama Y. The aryl hydrocarbon receptor: a multifunctional chemical sensor for host defense and homeostatic maintenance. Exp Anim. 2017;66(2):75-89. https://doi.org/10.1538/expanim.16-0092.

26. Jones S. An overview of the basic helix-loop-helix proteins. Genome Biol. 2004;5(6):226. https://doi.org/10.1186/gb-2004-5-6-226.

27. Mills NL, Donaldson K, Hadoke PW, Boon NA, MacNee W, Cassee FR, et al. Adverse cardiovascular effects of air pollution. Nat Clin Pract Cardiovasc Med. 2009;6(1):36-44. https://doi.org/10.1038/ncpcardio1399 https://www. ncbi.nlm.nih.gov/pubmed/19029991.
28. Brook RD. Cardiovascular effects of air pollution. Clin Sci (Lond). 2008;115(6): 175-87. https://doi.org/10.1042/CS20070444 https:/www.ncbi.nlm.nih.gov/ pubmed/18691154.

29. Simkhovich BZ, Kleinman MT, Kloner RA. Air pollution and cardiovascular injury epidemiology, toxicology, and mechanisms. J Am Coll Cardiol. 2008; 52(9):719-26. https://doi.org/10.1016/j.jacc.2008.05.029 https://www.ncbi. nlm.nih.gov/pubmed/18718418.

30. Gurgueira SA, Lawrence J, Coull B, Murthy GG, Gonzalez-Flecha B. Rapid increases in the steady-state concentration of reactive oxygen species in the lungs and heart after particulate air pollution inhalation. Environ Health Perspect. 2002;110(8):749-55. https://doi.org/10.1289/ehp.02110749 https:// www.ncbi.nlm.nih.gov/pubmed/12153754.

31. Gardner SY, Lehmann JR, Costa DL. Oil fly ash-induced elevation of plasma fibrinogen levels in rats. Toxicol Sci. 2000;56(1):175-80 https://www.ncbi.nlm nih.gov/pubmed/10869466.

32. Fujii T, Hayashi S, Hogg JC, Mukae H, Suwa T, Goto Y, et al. Interaction of alveolar macrophages and airway epithelial cells following exposure to particulate matter produces mediators that stimulate the bone marrow. Am J Respir Cell Mol Biol. 2002;27(1):34-41. https://doi.org/10.1165/ajrcmb.27.1. 4787 https://www.ncbi.nlm.nih.gov/pubmed/12091243.

33. Sun Q, Hong X, Wold LE. Cardiovascular effects of ambient particulate air pollution exposure. Circulation. 2010;121(25):2755-65. https://doi.org/10. 1161/CIRCULATIONAHA.109.893461 https:/www.ncbi.nlm.nih.gov/ pubmed/20585020.

34. Pope CA 3rd, Verrier RL, Lovett EG, Larson AC, Raizenne ME, Kanner RE, et al. Heart rate variability associated with particulate air pollution. Am Heart J. 1999;138(5 Pt 1):890-9 https://www.ncbi.nlm.nih.gov/pubmed/10539820.

35. Park SK, O'Neill MS, Vokonas PS, Sparrow D, Schwartz J. Effects of air pollution on heart rate variability: the VA normative aging study. Environ Health Perspect. 2005;113(3):304-9. https://doi.org/10.1289/ehp.7447 https:// www.ncbi.nlm.nih.gov/pubmed/15743719.

36. Rich DQ, Schwartz J, Mittleman MA, Link M, Luttmann-Gibson H, Catalano PJ, et al. Association of short-term ambient air pollution concentrations and ventricular arrhythmias. Am J Epidemiol. 2005;161(12):1123-32. https://doi. org/10.1093/aje/kwi143 https://www.ncbi.nlm.nih.gov/pubmed/15937021.

37. Dvonch JT, Kannan S, Schulz AJ, Keeler GJ, Mentz G, House J, et al. Acute effects of ambient particulate matter on blood pressure: differential effects across urban communities. Hypertension. 2009;53(5):853-9. https://doi.org/ 10.1161/HYPERTENSIONAHA.108.123877 https://www.ncbi.nlm.nih.gov/ pubmed/19273743.

38. Brook RD, Urch B, Dvonch JT, Bard RL, Speck M, Keeler G, et al. Insights into the mechanisms and mediators of the effects of air pollution exposure on blood pressure and vascular function in healthy humans. Hypertension. 2009;54(3):659-67. https://doi.org/10.1161/HYPERTENSIONAHA.109.130237 https://www.ncbi.nlm.nih.gov/pubmed/19620518.

39. Danielsen PH, Moller $P$, Jensen KA, Sharma AK, Wallin $H$, Bossi $R$, et al. Oxidative stress, DNA damage, and inflammation induced by ambient air and wood smoke particulate matter in human A549 and THP-1 cell lines. Chem Res Toxicol. 2011;24(2):168-84. https://doi.org/10.1021/tx100407m https:/www.ncbi.nlm.nih.gov/pubmed/21235221.

40. Jung MH, Kim HR, Park YJ, Park DS, Chung KH, Oh SM. Genotoxic effects and oxidative stress induced by organic extracts of particulate matter (PM 10) collected from a subway tunnel in Seoul, Korea. Mutat Res. 2012;749(12):39-47 https://www.ncbi.nlm.nih.gov/pubmed/23350069.

41. Robertson S, Thomson AL, Carter R, Stott HR, Shaw CA, Hadoke PW, et al. Pulmonary diesel particulate increases susceptibility to myocardial ischemia/ reperfusion injury via activation of sensory TRPV1 and beta1 adrenoreceptors. Part Fibre Toxicol. 2014;11:12. https://doi.org/10.1186/17438977-11-12 https://www.ncbi.nlm.nih.gov/pubmed/24568236.

42. Nelin TD, Joseph AM, Gorr MW, Wold LE. Direct and indirect effects of particulate matter on the cardiovascular system. Toxicol Lett. 2012;208(3): 293-9. https://doi.org/10.1016/j.toxlet.2011.11.008 https://www.ncbi.nlm.nih. gov/pubmed/22119171.

43. Gorr MW, Youtz DJ, Eichenseer CM, Smith KE, Nelin TD, Cormet-Boyaka E, et al. In vitro particulate matter exposure causes direct and lung-mediated indirect effects on cardiomyocyte function. Am J Physiol Heart Circ Physiol. 2015;309(1):H53-62. https://doi.org/10.1152/ajpheart.00162.2015 https:// www.ncbi.nlm.nih.gov/pubmed/25957217.

44. Tannheimer SL, Barton SL, Ethier SP, Burchiel SW. Carcinogenic polycyclic aromatic hydrocarbons increase intracellular $\mathrm{Ca} 2+$ and cell proliferation in primary human mammary epithelial cells. Carcinogenesis. 1997;18(6):1177- 
82. https://doi.org/10.1093/carcin/18.6.1177 https://www.ncbi.nlm.nih.gov/ pubmed/9214600

45. Bernshausen T, Jux B, Esser C, Abel J, Fritsche E. Tissue distribution and function of the aryl hydrocarbon receptor repressor (AhRR) in C57BL/6 and aryl hydrocarbon receptor deficient mice. Arch Toxicol. 2006;80(4):206-11. https://doi.org/10.1007/s00204-005-0025-5 https://www.ncbi.nlm.nih.gov/ pubmed/16205913.

46. Kerzee JK, Ramos KS. Activation of c-ha-ras by benzo(a) pyrene in vascular smooth muscle cells involves redox stress and aryl hydrocarbon receptor. Mol Pharmacol. 2000;58(1):152-8. https://doi.org/10.1124/mol.58.1.152 https://www.ncbi.nlm.nih.gov/pubmed/10860937.

47. Matsunaga T, Arakaki M, Kamiya T, Haga M, Endo S, El-Kabbani O, et al. Nitric oxide mitigates apoptosis in human endothelial cells induced by 9,10phenanthrenequinone: role of proteasomal function. Toxicology. 2010; 268(3):191-7. https://doi.org/10.1016/j.tox.2009.12.015 https://www.ncbi.nlm. nih.gov/pubmed/20026164.

48. Kumagai Y, Hayashi T, Miyauchi T, Endo A, Iguchi A, Kiriya-Sakai M, et al. Phenanthraquinone inhibits eNOS activity and suppresses vasorelaxation. Am J Physiol Regul Integr Comp Physiol. 2001;281(1):R25-30. https://doi. org/10.1152/ajpregu.2001.281.1.R25 https://www.ncbi.nlm.nih.gov/ pubmed/11404275.

49. Tofler GH, Muller JE. Triggering of acute cardiovascular disease and potential preventive strategies. Circulation. 2006;114(17):1863-72. https://doi. org/10.1161/CIRCULATIONAHA.105.596189 https://www.ncbi.nlm.nih.gov/ pubmed/17060396.

50. Sirenko O, Grimm FA, Ryan KR, Iwata Y, Chiu WA, Parham F, et al. In vitro cardiotoxicity assessment of environmental chemicals using an organotypic human induced pluripotent stem cell-derived model. Toxicol Appl Pharmacol. 2017;322:60-74. https://doi.org/10.1016/j.taap.2017.02.020 https://www.ncbi.nlm.nih.gov/pubmed/28259702.

51. Lee HH, Choi NR, Lim HB, Yi SM, Kim YP, Lee JY. Characteristics of oxygenated PAHs in PM10 at Seoul, Korea. Atmos Pollut Res. 2018;9(1):1128. https://doi.org/10.1016/j.apr.2017.07.007 <Go to |SI>:/WOS: 000429175800013.

52. Horikawa YT, Patel HH, Tsutsumi YM, Jennings MM, Kidd MW, Hagiwara Y, et al. Caveolin-3 expression and caveolae are required for isofluraneinduced cardiac protection from hypoxia and ischemia/reperfusion injury. J Mol Cell Cardiol. 2008;44(1):123-30. https://doi.org/10.1016/j.yjmcc.2007.10. 003 http://www.ncbi.nlm.nih.gov/pubmed/18054955.

\section{Publisher's Note}

Springer Nature remains neutral with regard to jurisdictional claims in published maps and institutional affiliations.

Ready to submit your research? Choose BMC and benefit from:

- fast, convenient online submission

- thorough peer review by experienced researchers in your field

- rapid publication on acceptance

- support for research data, including large and complex data types

- gold Open Access which fosters wider collaboration and increased citations

- maximum visibility for your research: over $100 \mathrm{M}$ website views per year

At BMC, research is always in progress.

Learn more biomedcentral.com/submissions 